\title{
The History and Pharmacology of Dopamine Agonists
}

\author{
X. Lataste
}

\begin{abstract}
The recognition of the dopaminergic properties of some ergot derivatives has initiated new therapeutical approaches in endocrinology as well as in neurology. The pharmacological characterization of the different ergot derivatives during the last decade has largely improved our understanding of central dopaminergic systems. Their development has yielded valuable information on the pharmacology of dopamine receptors involved in the regulatory mechanisms of prolactin secretion and in striatal functions.

The clinical application of such new neurobiological concepts has underlined the therapeutical interest of such compounds either in the control of prolactin-dependent endocrine disorders or in the treatment of parkinsonism. Owing to their pharmacological profiles, dopaminergic agonists represent a valuable clinical option especially in the management of Parkinson's disease in view of the problems arising from chronic L-Dopa treatment.
\end{abstract}

RÉSUMÉ: L'identification des propriétés dopaminergiques de certains dérivés de l'ergot a permis d'envisager de nouvelles approches thérapeutiques tant en endocrinologie qu'en neurologie. Au cours des dix dernières années, la caractérisation de leurs différents profils pharmacologiques, souvent complexes, a largement contribué au développement de nos connaissances sur les mécanismes dopaminergiques qui régissent la régulation de la sécrètion de prolactine ainsi que la régulation striatale des activités motrices. De plus, le développement de dérivés ergotés dopaminomimétiques a permis l'identification des différents sites récepteurs de la dopamine.

L'application clinique de ces nouveaux concepts neurobiologiques a révèlé l'intérêt porté à ces substances notamment dans le contrôle des désordres endocriniens prolactino-dépendants ainsi que dans le traitement de la maladie de Parkinson. De par leur pharmacologie, les agonistes dopaminergiques constituent, notamment dans le cadre de la maladie de Parkinson, une alternative clinique non négligeable aux problèmes liés au traitement chronique par la L-Dopa.

Can. J. Neurol. Sci. 1984; 11:118-123

"Until we are better informed respecting

the nature of this disease, the employment

of internal medicines is scarcely warrantable".

\section{J. PARKINSON, 1817.}

Twenty years ago, pharmacologists were preoccupied with the characterization of the $\alpha$-adrenergic and serotoninergic properties of ergot derivatives as potentially beneficial in the treatment of migraine.

However, for many years, interactions with reproductive functions have been reported to result from the use of certain ergot alkaloids. Contamination of sow-feed with ergot of Claviceps sp. (Shone et al., 1959; Loveless, 1967; Mantle, 1968a) or Sphacelia sp. (Mantle, 1968b) was responsible for endemic agalactia in sows. Despite these observations, the inhibitory effect of prolactin secretion induced by ergot alkaloids and their derivatives was first suggested by Shelesnyak (1954). This original report underlined the inhibitory effects upon deciduoma formation and ovum implantation in the rat uterus induced by ergotoxine. This effect, reversed by injections of progesterone or prolactin (Shelesnyak, 1958), was indicative of a direct (pituitary) or indirect (hypothalamus) inhibition of prolactin secretion induced by ergotoxine.

This hypothesis was confirmed by Zeilmaker and Carlsen (1962). At that time, ergot chemists and pharmacologists in our laboratories began their search for an ergot alkaloid or a derivative which would selectively inhibit prolactin secretion as its main action.

Among various compounds tested, 2-bromo- $\alpha$-ergocryptine methanesulfonate (bromocriptine) was the most promising structure exhibiting such a specific action upon prolactin secretion. Bromocriptine (for synthesis and activity see e.g. Schneider et al., 1977), was chosen to be developed for testing in human in 1967. However the existence of human prolactin, as a separate pituitary hormone, was negated by most endocrinologists (Geschwind, 1972) except Pasteels (1973). Moreover, there was no receptor concept in support of a possible inhibition of prolactin secretion, adrenoceptors and serotonin receptors not being involved.

The clinical situation was dramatically changed by the recognition of human prolactin ( $\mathrm{h} \mathrm{Prl}$ ) as a discrete hormonal entity (Frantz et al., 1970; Hwang et al., 1971; Lewis et al., 1971; Loewenstein, 1971; Turkington, 1971) and the concomitant development of a suitable radio-immunoassay for $\mathrm{h} \mathrm{Prl}$ (Hwang, 1971).

As the prolactin concept was developed, bromocriptine was intensively investigated to improve our understanding of its action profile. Among the various investigations performed, the interaction of bromocriptine and ergocornine with hypothalamic catecholaminergic neurons (Fuxe et al., 1970; Hoekfelt 
et al., 1972) provided an essential clue in ergot pharmacology by demonstrating their ability to reduce dopamine (DA) turnover in hypothalamic and neostriatal dopaminergic neurons. Such central dopaminomimetic properties were confirmed by Corrodi et al. (1973), Myamoto et al. (1974) and Johnson et al. (1976). Hence the ability to stimulate DA receptors was recognized for ergot compounds and the clinical relevance of this property was soon demonstrated in patients with Parkinson's disease (Calne et al., 1974a and b).

However, the nature of the regulation of prolactin secretion was still unknown. The link between DA receptor stimulation and inhibition of prolactin secretion induced by bromocriptine was clearly demonstrated only somewhat later (Flueckiger et al., 1976; MacLeod, 1976).

This brief review of the most recent aspects of the development of the pharmacology of ergot derivatives underlines the broad spectrum of their potential activities resulting from their ability to interact with different receptor systems.

\section{Dopaminomimetic Agents and Parkinson's Disease}

The clinical use of dopaminergic compounds in the treatment of Parkinson's disease was suggested by Fuxe et al. (1970) and established by Calne et al. (1974a). However, ergot derivatives were proposed a century ago in the treatment of paralysis agitans, on the basis of their parasympatholytic properties. Charcot (1892) reported the lack of beneficial effects of ergot alkaloids as well as for atropa belladona in parkinsonian patients. At that time, only low-molecular-weight ergot alkaloids were used in such clinical conditions. In the early 1940's, it was proposed mainly in Germany, to use a dry extract of bovine striatum for parkinsonism. The drug, called Striaphorin, was produced for some years without any significant success. We know now that if the active principle of such a preparation was dopamine, this could never cross the blood-brain barrier to reach its target.

The first real attempts to use dopaminergic agents in the treatment of Parkinson's disease were made when the dopamine theory of Parkinson's disease was verified (Ehringer and Hornykiewicz 1960, Barbeau, 1960). Apomorphine was a prime clinical candidate after the identification of its pharmacologic similarities with dopamine (Ernst, 1967; Ungerstedt et al., 1969).
Despite its beneficial effect in early clinical trial (Cotzias et al., 1970, Castaigne et al., 1977), the use of apomorphine appears to be limited clinically owing to its nephrotoxicity (Papavasiliou et al., 1978), strong emetic action, rapid metabolism and lack of oral activity (Castaigne et al., 1971; Schwab, 1951). Some derivatives of apomorphine (n-propyl-norapomorphine) were proposed (Cotzias et al., 1976; Papavasiliou et al., 1978).

The profile of apomorphine-as a dopaminergic stimulant and its beneficial effects upon parkinsonian symptoms had encouraged the search for other dopaminomimetic agents. A dopaminergic profile was proved for different ergoline derivatives, including bromocriptine (Corrodi et al., 1973; Fuxe et al., 1978), lergotrile (Fuller and Perry, 1978; Wong and Bymaster, 1978), pergolide (Fuller et al., 1979; Wong et al., 1979) and lisuride (Graf et al., 1976), indicating their possible use for the management of parkinsonism.

More recently a number of other ergot compounds have also been found to interact with DA receptors within the striatum, e.g. CH 29-717, CQ 32-084 and CU 32-085 (Flueckiger et al., 1979).

For many of these dopaminomimetic agents, the starting point for chemists was the ergoline skeleton of ergot leading to three ergot families: clavines, lysergic acid amides and $8 \alpha$-amino-
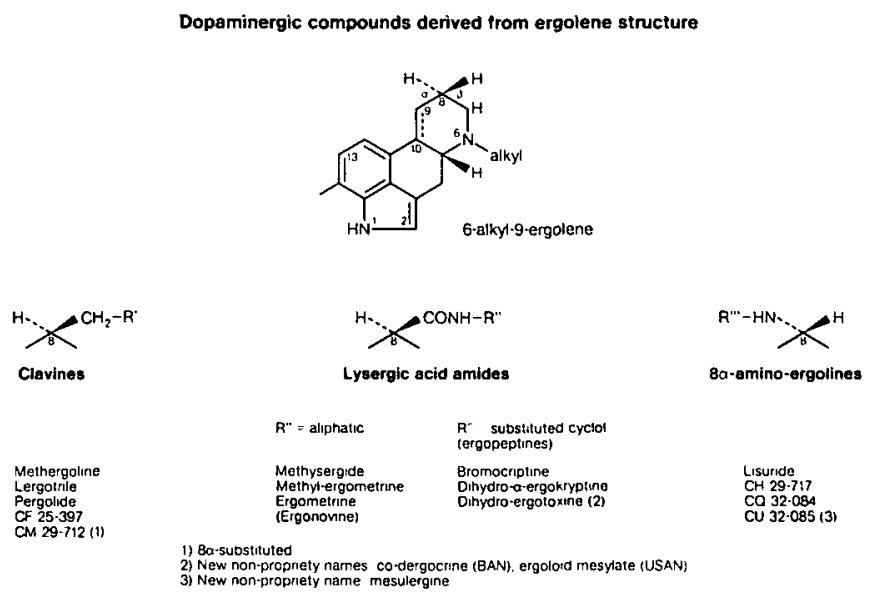

Figure I-Chemical structures of the different families of ergot compounds exhibiting dopaminomimetic properties. (from Vigouret et al., 1978; Flueckiger et al., 1979, 1983b).

\begin{tabular}{|c|c|c|c|c|c|c|c|c|c|}
\hline \multirow[b]{3}{*}{ Ergopeptine $=$ Bromocriptine } & \multirow{3}{*}{$\begin{array}{c}\text { Prl } \begin{array}{c}(1) \\
\delta \text { Rat }(2 \mathrm{hr})\end{array} \\
\frac{\mathrm{ID}_{50}(\mu / \mathrm{kg} \text { s.c. })}{8}\end{array}$} & \multirow{3}{*}{$\begin{array}{c}(2) \\
\begin{array}{c}\text { Turning Behaviour } \\
\text { Ungerstedt Rat } \\
\text { MED }(\mu \mathrm{g} / \mathrm{kg})\end{array} \\
100 \text { s.c. }\end{array}$} & \multirow{3}{*}{$\begin{array}{c}(3) \\
\begin{array}{c}\text { Ach Release } \\
\text { Rat Striatum } \\
\text { IC }_{50}(\mathbf{n M})\end{array} \\
5.0\end{array}$} & \multirow{3}{*}{\begin{tabular}{l}
\multicolumn{1}{c}{$(\mathbf{4})$} \\
DA Release \\
Rat Striatum \\
Ag. (nM)
\end{tabular}} & \multicolumn{3}{|c|}{$\begin{array}{c}(5) \\
\text { DA - AC } \\
\text { Rat Striatum }\end{array}$} & \multicolumn{2}{|c|}{$\begin{array}{c}\text { (6) } \\
\text { Calf Caudatum } \\
\text { 3H-DA/3H-Spiro }\end{array}$} \\
\hline & & & & & \multirow{2}{*}{$\frac{\mathbf{E r}}{\emptyset}$} & \multicolumn{2}{|c|}{$\mathrm{pD}_{2} / \mathbf{p K} \mathbf{i}$} & \multicolumn{2}{|c|}{$I C_{50}(n M)$} \\
\hline & & & & & & & 6.4 & 84 & 13 \\
\hline $\begin{aligned} & \text { Clavines }= \text { Lergotrile } \\
& \text { Pergolide } \\
& \text { CF 25-397 } \\
& \text { CM 29-712 } \\
&\end{aligned}$ & $\begin{array}{c}16 \\
0.44 \\
720 \\
16 \\
\end{array}$ & $\begin{array}{r}100 \text { s.c. } \\
10 \text { s.c. } \\
300 \text { s.c. } \\
50 \text { i.p. }\end{array}$ & $\begin{array}{l}3.2 \\
40.0 \\
\text { Antag. }\end{array}$ & 0 & $\begin{array}{r}0 \\
30 \\
34 \\
34 \\
\end{array}$ & $\begin{array}{l}6.0 \\
6.6 \\
5.4\end{array}$ & $\begin{array}{c}6.2 \\
0 \\
0 \\
0\end{array}$ & & \\
\hline $\begin{aligned} & \text { Amino-Ergoline }= \text { Lisuride } \\
& \text { CH 29-717 } \\
& \text { CQ 32-084 } \\
& \text { Mesulergine } \\
&\end{aligned}$ & $\begin{array}{l}3.9 \\
0.89 \\
5 \\
10 \\
\end{array}$ & $\begin{array}{l}10 \text { s.c. } \\
50 \text { i.p. } \\
10 \text { s.c. } \\
300 \text { s.c. }\end{array}$ & $\begin{array}{l}5.0 \\
2.5 \\
1580 \\
\end{array}$ & $\begin{array}{l}\text { Ag. }(\mu \mathrm{M}) \\
\text { Antag. }\end{array}$ & $\begin{array}{r}0 \\
0 \\
32 \\
0 \\
\end{array}$ & 5.8 & $\begin{array}{c}7.0 \\
<5 \\
0 \\
6.3 \\
\end{array}$ & $\begin{array}{r}210 \\
120 \\
1400 \\
\end{array}$ & $\begin{array}{r}120 \\
25 \\
140 \\
\end{array}$ \\
\hline $\begin{array}{l}\text { Dopamine } \\
\text { Apomorphine }\end{array}$ & 1800 & 10 & $\stackrel{?}{25.0}$ & $\begin{array}{c}\text { Ag. (?) } \\
\text { Ag. (nM) }\end{array}$ & $\begin{array}{r}100 \\
69\end{array}$ & $\begin{array}{l}6.3 \\
6.3\end{array}$ & 0 & & \\
\hline
\end{tabular}

Results from (1) Flueckiger et al. (1979); (2) Vigouret et al. (1978); (3)-(5) Markstein (1981) and unpublished; (6) Closse et al. (1980). 
Table 2: Comparison of neurochemical properties: bromocriptine and mesulergine (from Markstein, unpublished)

(1)

\begin{tabular}{cr}
\multicolumn{3}{c}{ DA Receptors } \\
\hline $\begin{array}{cr}\text { DA }- \text { AC }(+) & \text { DA }- \text { AC }(-) \\
(\mathbf{D} 1) & \text { (D2) } \\
- & +++ \\
- & +++\end{array}$
\end{tabular}

(2)

5HT-Receptors

$\left(5 \mathrm{HT}_{2}\right)$
(3)

Adrenoreceptors

$\alpha 1+\alpha 2$

\begin{tabular}{|c|c|c|c|c|}
\hline Bromocriptine & - & $+t+$ & -- & -- \\
\hline Mesulergine (CU 32-085) & - & $+t+$ & $\frac{++}{\text { (Antagonism) }}$ & - \\
\hline
\end{tabular}

Table 3: Comparison of clinical profiles of ergot derivatives in Parkinson's disease (from Rinne, 1983 with permission)

\begin{tabular}{|c|c|c|c|c|c|c|c|}
\hline \multirow[b]{2}{*}{ Compound } & \multicolumn{2}{|c|}{ Therapeutic Response } & \multicolumn{5}{|c|}{ Adverse Reactions } \\
\hline & $\begin{array}{c}\text { Antiparkinsonian } \\
\text { efficacy }\end{array}$ & $\begin{array}{l}\text { Mood } \\
\text { elevation }\end{array}$ & $\begin{array}{l}\text { Nausea - } \\
\text { vomiting }\end{array}$ & $\begin{array}{c}\text { Cardiovascular } \\
\text { activity* }^{*}\end{array}$ & Sedation & $\begin{array}{c}\text { Hallucinations } \\
+ \text { confusion }\end{array}$ & Dyskinesia \\
\hline Bromocriptine & + & + & ++ & + & ++ & $+t$ & + \\
\hline CM 29-712 & + & - & +++ & + & +++ & \pm & - \\
\hline CQ 32.084 & ++ & + & ++ & ++ & $+t$ & ++ & - \\
\hline CU 32-085 & + & $+t+$ & + & \pm & $+t$ & + & - \\
\hline
\end{tabular}

${ }^{*}$ Decrease of blood pressure and the occurrence of postural hypotension.

Effect of mesulergine on DOPAC in rat striatum

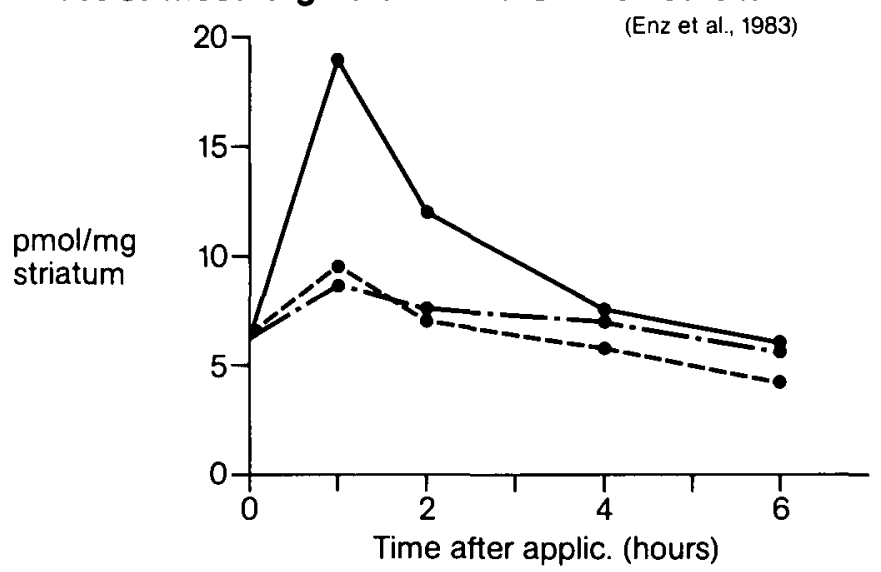

$\longleftrightarrow 3.2 \mathrm{mg} / \mathrm{kg}$ s.c. $\bullet-\longrightarrow 10 \mathrm{mg} / \mathrm{kg}$ p.o. $\bullet-\longrightarrow 3.2 \mathrm{mg} / \mathrm{kg}$ i.p.

Figure $2-$ Effect of Mesulergine on DOPAC level in rat striatum. (from Enz et al., 1983 with permission)

ergolines (Fig. 1). The pharmacological profile of these derivatives is quite different in terms of structure-activity relationships as agonists and/or antagonists upon $\alpha$-adrenoreceptors, serotonine receptors and DA receptors. The pharmacology of ergot alkaloids and their derivatives has been extensively reviewed recently (Berde and Schild, 1978; Clark et al., 1978; Fuxe, 1979; Thorner et al., 1980; Flueckiger et al., 1981; Lataste, 1981; Flueckiger and Markstein, 1982; Flueckiger, 1983a; Flueckiger et al., 1983b; Tran et al., 1983; Calne, 1983; Fuxe et al., 1983). In Table 1 are summarized the available pharmacological data of a number of ergot compounds of proven activity in parkinsonism, compared with apomorphine and dopamine.

\section{Specific Aspects of Ergot Pharmacology}

Among the various pharmacological aspects of ergot derivatives, I would like to concentrate my review upon some pharmacodynamic properties which could be relevant for their therapeutic use. When central dopaminergic activities are compared, quite different overall potency profiles can be characterized.
Compared with bromocriptine, mesulergine $(\mathrm{CU} 32-085)$ as a 8 - $\alpha$-amino-ergoline derivative has a different potency in in vivo models (Table 1).

The distinctive pharmacological profiles obtained from ergot derivatives include not only their specific interactions with the different subtypes of DA receptors but also their possible interferences with other transmitter receptors including adrenoceptors and serotonine receptors (Table 2).

Such a complex pharmacology suggests that these compounds may induce different clinical responses in the management of parkinsonian symptoms. However, the clinical results so far obtained with these compounds (Rinne, 1983) do not yet allow correlation of their efficacy and tolerability with their respective pharmacological profile (Table 3 ).

Moreover, for some of these compounds, their metabolic pattern appears to be essential to explain their activities. As an example, mesulergine seems to exhibit a biphasic action on the DA turnover: after an initial receptor blockade, an agonistic effect was observed only 4 hours later (Flueckiger et al, 1979; Enz, 1981, 1982; Ringwald et al., 1982). However, this effect was mainly observed after subcutaneous administration (Fig. 2). When the compound is given orally, the initial activation of DA turnover is much reduced (Enz et al., 1983). Such a difference can be explained by the metabolic pattern of this agent, which is actively and rapidly transformed into various metabolites. Among these metabolites, the major two ( $\mathrm{CH} 29-717$ and 204-079) exhibit potent dopaminergic properties. In addition to the metabolic pattern, it is important to compare the pharmacokinetics of these agents within the plasma and the striatum as the target organ.

The claimed advantage of dopaminergic drugs over L-Dopa was the longer half-life inducing a longer clinical benefit. However such a statement was referring only to the plasma kinetic properties, not taking into account the drug kinetics within the target organ, i.e. the striatum. With mesulergine, however, this last effect was investigated. After an oral dose of $10 \mathrm{mg} / \mathrm{kg}$ (Fig. 3 ), there is in the striatum a rapid appearance of the active metabolites with a concomitant decrease of the parent drug (Enz et al., 1983).

Another controversial aspect of ergot pharmacology concerns the concept of DA-receptors (see Seeman P. and Kebabian J.) 


\section{Comparative pharmacokinetics of mesulergine and metabolites \\ (Enz et al.. 1983)}

a

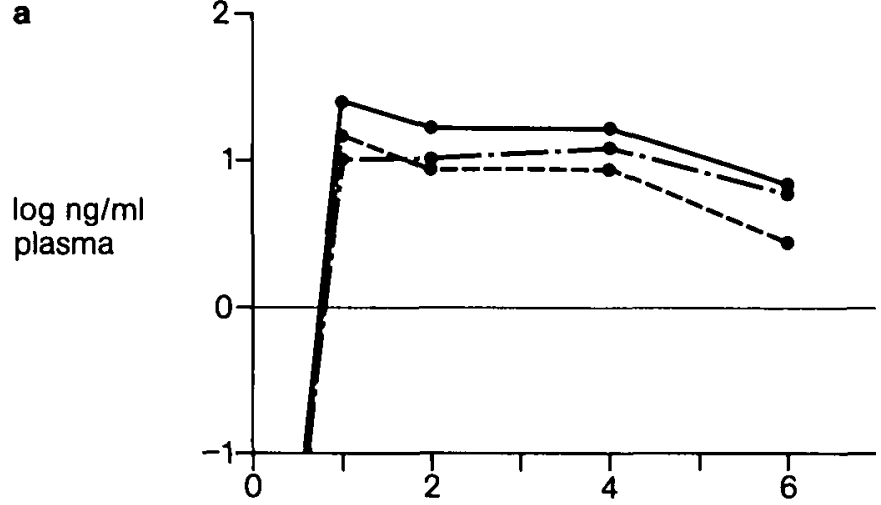

b

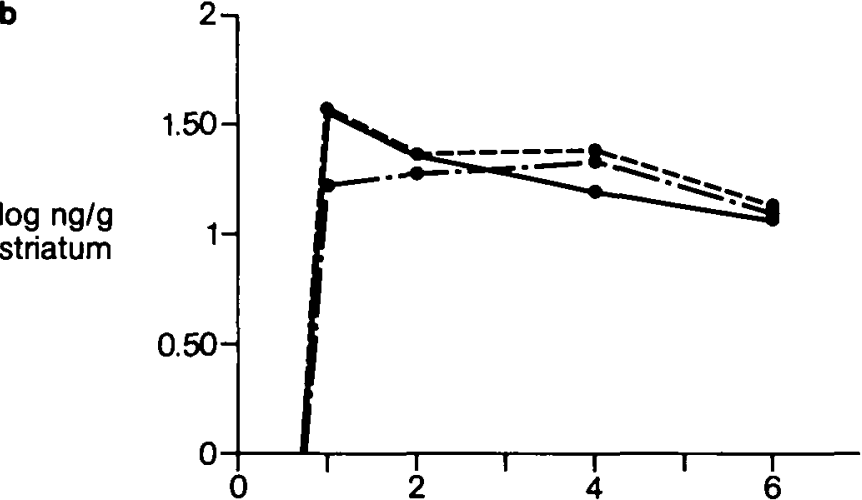

Hours after p.o. applic. $10 \mathrm{mg} / \mathrm{kg}$

\section{$\bullet$ CU 32-085}

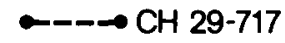

$\bullet \cdot 204-079$

Figure 3 - Comparative pharmacokinetics of Mesulergine and metabolites in plasma and striatum. (from Enz et al., 1983 with permission).

In animal models, the central dopaminergic activities of bromocriptine were investigated mainly in acute conditions. Few data are available upon the effects observed during chronic administration. Recently such a chronic treatment was performed (Vigouret et al., 1983) in the stereotyped behaviour model in intact rats as well as in the Ungerstedt model.

As reviewed in Table 4, behavioural dopaminergic stereotypies were generally observed with acute doses over $30 \mathrm{mg} / \mathrm{kg}$ given orally. In chronic conditions, pronounced stereotypies appeared after 5 weeks at a daily dose of $12 \mathrm{mg} / \mathrm{kg}$ with a concomitant significant decrease of DOPAC level within the striatum. The DA turnover was not significantly influenced in acute stimulation. These observations indicate the appearance of a behavioural and biochemical hypersensitivity to bromocriptine during the chronic use of oral doses inactive when given acutely. Moreover the unilateral lesioning of nigrostriatal pathways by local injection of 6-OH-DA leads to a supersensitivity of DA receptors within the striatum. Dopaminomimetic agents such as apomorphine or bromocriptine induce a contralateral turning behaviour by stimulation of the "denervated" DA receptors. Such behaviour was observed for acute doses of bromocriptine over $9 \mathrm{mg} / \mathrm{kg}$, but reproducible effects were obtained with $20 \mathrm{mg} / \mathrm{kg}$. A comparable turning pattern was recorded in chronic condition after the third week at a daily dose of $6 \mathrm{mg} / \mathrm{kg}$ (Table 5). The latency of the turning behaviour was about 2 hours, followed by a longer period of dopaminergic stimulation (more than 7 hours).

The comparison of the effects obtained after either acute or chronic administration points out the complex pharmacology of dopaminergic agents. A repeated administration seems to induce a functional supersensitivity probably related to postsynaptic DA receptors. However the participation of other DA receptors cannot be excluded, i.e. presynaptic DA receptors. The biochemical mechanisms underlying such dynamic aspects of receptor stimulation are still unknown. However the clinical implication of these results appears to be essential especially for the initiation of dopaminergic agents in parkinsonian patients. The titration period should be carefully built-up before the onset of an optimal effect. The therapeutic response seems to require a certain delay, depending for each patient upon the dynamic situation of his DA receptor systems. Moreover the antiparkinsonian effect can increase over time without additional increase in the daily regimen after the appearance of the first signs of clinical improvement.

These pharmocological elements emphasize the complexity of the DA receptor concept. From biochemical in vitro tests, it seems difficult to extrapolate to in vivo conditions related to Parkinson's disease. Our understanding of the dynamics of receptors is yet quite uncertain, as is that of the compensatory mechanisms which probably take place during the natural progression of the degenerative process.

Table 4: Effects of acute and chronic administration of bromocriptine in stereotyped behaviour (from Vigouret, unpublished)

\begin{tabular}{lccc}
\hline \hline & $\begin{array}{c}\text { Dose } \\
\mathbf{m g} / \mathbf{k g} \text { p.o. }\end{array}$ & $\begin{array}{c}\text { Score } \\
(\mathbf{N}=\mathbf{6})\end{array}$ \\
\hline Acute Dose & 3 & & $0.6 \mp 0.7$ \\
& 10 & & $0.6 \mp 0.8$ \\
& 30 & $7.3 \mp 1.2(\mathrm{p}<0.05)$ \\
\hline Control & & $0.5 \mp 0.4$ \\
\hline & Dose & & Score \\
& mg/kg p.o./Day & Week & $(\mathbf{N = 6 )}$ \\
\hline Chronic Dose & 1 & 1 & $0.3 \mp 0.3$ \\
& 3 & 2 & $0.3 \mp 0.2$ \\
& 6 & 3 & $0.4 \mp 0.2$ \\
& 9 & 4 & $0.8 \mp 0.3$ \\
& 12 & 5 & $13.4 \mp 1.3(\mathbf{p}<0.01)$ \\
\hline
\end{tabular}

Table 5: Effects of acute and chronic administration of bromocriptine in Ungerstedt model (from Vigouret, unpublished)

\begin{tabular}{lccc}
\hline \hline & $\begin{array}{c}\text { Dose } \\
\mathbf{m g} / \mathbf{k g} \text { p.o. }\end{array}$ & Week & $\begin{array}{c}\text { Total Number of } \\
\text { Contralat. Rotations } \\
(\mathbf{7} \text { h. })\end{array}$ \\
\hline Acute Dose & 1 & - & 0 \\
$(\mathrm{~N}=6)$ & 3 & & 0 \\
& 6 & & $152 \mp 21$ \\
& 9 & $1600 \mp 185$ \\
\hline Chronic Dose & 20 & 1 & $24 \mp 14$ \\
$(\mathrm{~N}=12)$ & 1 & 2 & $15 \mp 57$ \\
& 3 & 3 & $1093 \mp 200$ \\
& 6 & 4 & $1080 \mp 320$ \\
\hline
\end{tabular}


As an example, the balanced activation of 2 types of DA receptors (pre- and post-synaptic) seems to be essential for an adequate integration of striatal functions. The mechanisms underlying this balance are still unknown within normal physiological conditions as well as during the natural course of the degenerative process underlying Parkinson's disease (Flueckiger and Vigouret, 1981).

\section{Conclusions}

In recent years, the dopaminergic properties of ergot compounds have attracted much attention whereas other aspects of their receptor pharmacology still remain unclear. Moreover small differences within their chemical structure may produce qualitative changes in their profile of actions. Particularly interesting is the possible relationship between in vivo and in vitro activities to explain such a multiplicity of profiles. Ergot derivatives have had an important impact on our understanding of central dopaminergic functions and have served as useful tools for pharmacological research. However, the DA receptor concept is not yet satisfactory, especially when confronted to its clinical implications. The clinical contribution of dopaminomimetic ergots is essential but far from being completely understood. New approaches, perhaps more specific ones, are required to provide ample and clear information to optimize their pharmacodynamic properties. According to their mechanism of action, they allow continued treatment for parkinsonian patients who become resistant to L-Dopa or no longer tolerate it because of adverse reactions, such as dyskinesia or "on-off" phenomenon (Lieberman et al., 1976; Calne et al., 1978; Ringwald, 1982).

In newly diagnosed patients, dopaminergic agents such as bromocriptine or mesulergine may represent an alternative to chronic L-Dopa treatment. According to preliminary results (Lees et al., 1978; Rascol et al., 1982; Hirt et al., 1983) these compounds given as monotherapy had a low potential for producing dyskinesia or "on-off" phenomenon over at least 5 years. The extension of this experience over time is essential to provide clear evidence of the therapeutical potential of ergots in the chronic management of parkinsonism, avoiding the disabling problems associated with L-Dopa.

Despite the real improvement in the quality of life of parkinsonian patients with L-Dopa and/or dopaminergic agents, the natural course of disease remains unchanged. In this respect no real progress was made since the optimistic conclusion of Parkinson (1817) in his original essay:

"There appears to be sufficient reason for hoping that some remedial process may ere long be discovered by which at least the progress of the disease may be stopped".

Recently new prospects were offered to pharmacologists with the recognition of chemically induced parkinsonism in young addicts (Davis et al., 1979; Langston et al., 1983; Burns et al., 1983). The development of a more accurate model for parkinsonism in rhesus monkeys receiving NMPTP (N-methyl4-phenyl-1,2,3,6-tetrahydropyridine) could probably improve our understanding of the basic pathological mechanism of parkinsonian degeneration. This model, if it truly reproduces the neurological syndrome, could be a useful tool in the selection of new antiparkinsonian drugs among ergot derivatives. This is the future challenge offered to neuropharmacology.

\section{ACKNOWLEDGEMENTS}

I would like to thank E. Flueckiger, J. M. Vigouret and A. Enz for their kind contribution in the preparation of this manuscript.

\section{REFERENCES}

Barbeau A (1960) Preliminary observation on abnormal catecholamine metabolism in basal ganglia disease. Neurology 10, 5: 446-451.

Berde B, Schild HO (Editors) (1978) Ergot alkaloids and related compounds. Springer Verlag, Berlin.

Burns RS, Chiveh CC, Markey SP, Ebert MM, Jacobowitz DM, Kopin IJ (1983) A primate model of parkinsonism: selective destruction of dopaminergic neurons in the pars compacta of the substantia nigra by 1-methyl-4-phenyl-1,2,3,6-tetrahydropyridine. Proc. Natl. Acad. Sci. USA 80: 4536-4550.

Calne DB, Teychenne PF, Claveria LE, Eastman R, Greenacre JK, Petrie A (1974a) Bromocriptine in parkinsonism. Br. Med. J. 4: 442-444.

Calne DB, Teychenne PF, Leigh PN, Bamji AN, Greenacre JK (1947b) Treatment of parkinsonism with bromocriptine. Lancet 2: 1355-1356.

Calne DB, Williams AC, Nutt JG, Neophytides A, Eisler T, Teychenne PF (1978) Ergot derivatives for parkinsonism. Med. J. Austr. 2, 3 (Suppl) 25-36.

Calne DB (1983) Ergot derivatives and extrapyramidal disease $I n$ : Lisuride and other dopamisne agonists. Calne DB et al. (Eds.) pp. 357-361, Raven Press, New-York.

Castaigne P, Laplane D, Dordain G (1971) Clinical experimentation with apomorphine in Parkinson's disease. Res. Commun. Chem. Pathol. Pharmacol. 2: 154-158.

Charcot JM (1892) Leçons sur les maladies du système nerveux faites à la Salpêtrière. Recueillies et publiées par Bourneville A. Paris, pp. 155-188. Delahaye et Lecrosnier.

Calne DB, Larsen TA (1983) Potential therapeutic use of dopamine receptor agonist and antagonist In: Dopamine Receptors - ACS Symposium Series 244, Kaiser C and Kebabian JW (Eds.) Amer. Chem. Soc., Washington.

Clark BJ, Flueckiger E, Loew DM, Vigouret JM (1978) How does bromocriptine work? Triangle 17, 1:21-31.

Closse A, Frick W, Hauser D, Sauter A (1980) Characterization of 3 H-bromocriptine binding to calf caudate membranes. In: Psychopharmacology and biochemistry of neurotransmitter receptors. Yamamura $\mathrm{HI}$ et al., (Eds.) Elsevier, North Holland, Amsterdam pp. 463-474.

Corrodi H, Fuxe K, Hokfelt T, Lidbrink P, Ungerstedt U (1973) Effect of ergot drugs on central catecholamine neurons: Evidence for a stimulation of central dopamine neurons. J. Pharm. Pharmacol., 25: 409-411.

Cotzias GC, Papavasiliou PS, Fehling C, Kaufman B, Mena I (1970) Similarities between neurological effects of $\mathrm{L}$-dopa and apomorphine. N. Engl. J. Med. 282: 31-33.

Cotzias GC, Papavasiliou PS, Tolosa ES, Mendez JS, Bell-Mindura M (1976) Treatment of Parkinson's disease with apomorphines. Possible role of growth hormone. N. Engl. J. Med. 294: 567-572.

David GC, William AC, Markey SP, Ebert MH, Caine ED, Reichert CM, Kopin IJ (1979) Psychiatry Res. I: 249-254.

Ehringer H, Hornykiewiez O (1960) Verteilung von Noradrenalin und Dopamin (3-Hydroxytyramin) in dem Menschen und ihr Verhalten bei Erkrankungen des Extra-pyramidalen Systems. Klin. Wschr. 38: 1236-1239.

Enz A (1981) Biphasic influence of an 8- $\alpha$-amino ergoline, CU 32-085, on striatal dopamine synthesis and turnover in vivo in the rat. Life Sci. 29: 2227-2234.

Enz A, Frick A, Closse A, Nordmann R (1982) Dopaminergic properties of CU 32-085 and its 1,20-N,N-bidemethylated metabolite. In: Abstr. CINP Meeting, Jerusalem, Vol. 1, p. 199

Enz A, Donatsch P, Nordmann R (1983) Dopaminergic properties of Mesulergine (CU 32-085) and its metabolites. J. Neural. Transm. (in press).

Ernst AM (1967) Mode of action of apomorphine and dexamphetamine on gnawing compulsion in rats. Psychopharmacology 10: 316-323.

Flueckiger E (1970) The pharmacology of bromocriptine In: Pharmacological and Clinical Aspects of Bromocriptine (Parlodel). Bayliss 
IS, Turner $\mathrm{P}$ et al., (Eds.), MCS consultants, Turnbridge Wells, Kent pp. 12-26.

Flueckiger E, Briner U, Buerki HR, Marbach P, Wagner HR, Doepfner W (1979) Two novel prolactin release-inhibiting 8- $\alpha$-amino-ergolines. Experientia 35: 1677-1678.

Flueckiger E, Vigouret JM (1981) Central dopamine receptors. Postgrad. Med. J. Suppl, I, 57: 55-61.

Flueckiger E, Markstein R (1982) Receptor pharmacology of ergot compounds. In: Proc. Third Intern. Meeting on Human Prolactin. Tolis G (Ed.) Raven Press, New-York (in press).

Flueckiger E (1983a) Interactions of ergot compounds with dopamine receptors and endocrine functions. J. Neural. Transmission Suppl. 18: 189-204

Flueckiger E, Briner U, Enz A, Markstein R, Vigouret JM (1983) Dopaminergic ergot compounds: an overview $/ n$ : Lisuride and other dopamine agonists. Calne DB et al., (Eds.) Raven Press, New-York pp. 1-9.

Frantz AG, Kleinberg DL (1970) Prolactine: evidence that it is separate from growth hormone in human blood. Science 170: 745-747.

Fuller RW, Perry KW (1978) Effect of lergotrile on 3,4-dihydroxyphenylacetic acid (DOPAC) concentration and dopamine turnover in rat brain. J. Neurol. Transm. 42: 23-25.

Fuller RW, Clemens JA, Kornfeld EC, Snoddy HD, Smalstig EB, Bach NJ (1979) Effects of (8-beta)-8-(methylthio) methyl-6-propylergoline on dopaminergic function and brain dopamine turnover in rats. Life Sci. 24: 375-382.

Fuxe K, Hokfelt T (1970) Central monoaminergic systems and hypothalamic function In: The Hypothalamus. Martini L et al., (Eds.) Academic Press, New-York, pp. 123-138.

Fuxe K, Fredholm BB, Agnati LF, Ogren SO, Everitt BJ, Gustafsson JA (1978) Interaction of ergot drugs with central monoamine systems: Evidence for high potential in the treatment of mental and neurological disorders. Pharmacology 16, Suppl. 99-134.

Fuxe K (1979) Dopamine receptor agonists in brain research and as therapeutic agents. TINS 2: 1-4.

Fuxe K, Agnati LF, Kohler C, Andersson K, Eneroth P, Calza L, Ogren SO (1983) Heterogeneity of brain dopamine systems: Possible discrimination of different types of dopamine systems and receptors by ergot drugs. In: Lisuride and other dopamine agonists, Calne DB et al., (Eds.) Raven Press, New-York, pp. 11-31.

Geschwing II (1972) Introduction. In: Prolactin and Cardiogenesis, Boyns AR, Griffiths K, (Eds.) Alpha Omega. Alpha Publishing, Cardiff pp. 1-3.

Graf KJ, Neumann T, Horowski R (1976) Effect of the ergot derivative lisuride hydrogen maleate on serum prolactin concentrations in female rats. Endocrinology 98: 598-605.

Hirt D, Lataste X, Ringwald E (1983) Mesulergine over one year. In First symposium on Restorative Neurology, Venice p. 33 (abstr.).

Hokfelt T, Fuxe K (1972) On the morphology and the neuroendocrine role of the hypothalamic neurons. In: Brain-Endocrine Interaction. Median Eminence: Structure and Function. Knigge KM et al., (Eds.). Karger, Basel, pp. 181-223.

Hwang P, Friesen H, Hardy J, Wilansky D (1971a) Biosynthesis of human growth hormone and prolactin by normal pituitary glands and pituitary adenomas. J. Clin. Endocrinol. 33: 1-7.

Hwang P, Guida H, Friesen HG (197/b) A radio-immunoassay for human prolactin. Proc. Natl. Acad. Sci. USA 68: 1902-1906.

Johnson AM, Loew DM, Vigouret JM (1976) Stimulant properties of bromocriptine, amphetamine and L-Dopa. J. Pharmacol. 56: 59-68.

Langston JW, Ballard P, Tetrud JW, Irwin I (1983) Chronic parkinsonism in humans due to a product of meperidine analog synthesis. Science 219: 979-980.

Lataste X(1981) Bromocriptine et maladie de Parkinson: revue clinique et prospective. In: Colloque sur la bromocriptine. Sandoz Edition, Paris, pp. 277-293.

Lees AJ, Haddad S, Shaw KM, Kohout LJ, Stern GM (1978) Bromocriptine in the Parkinson's disease - a long-term study. Arch. Neurol. 35: 503-507.

Lewis UJ, Singh RNP, Sinha YN, Van Der Laan WP (1971) Electrophoresis evidence for human prolactin. J. Clin. Endocrinol. 33: 153-156.

Lieberman A, Kupersmith M, Estey E, Goldstein M (1976) Modification on the on-off effect with bromocriptine and lergotrile. N. Engl. J. Med. 295: 1400-1401.
Loewenstein JE, Mariz IK, Peake GT, Daughaday WH (1971) Prolactin bioassay by induction of $\mathrm{N}$-acetyllactosamine synthetase in mouse mammary explants. J. Clin. Endocrinol. 33: 217-224.

Loveless AR (1967) Claviceps fusiformis $\mathrm{sp}$. nov., the causal agent of an agalactia of sows. Transm. Br. Mycol. Soc. 50: 15-18.

MacLeod RM, Lehmeyer JE (1974) Studies on the mechanism of the dopamine mediated inhibition of prolactin secretion. Endocrinology 94: 1077-1085.

Mantle PG (1968) Studies on Sphacelia Sorghi Mc.Rae, an ergot of Sorghum vulgare Pers. Ann. Appl. Biol. 62: 443-449.

Mantle PG (1969) Interruption of early pregnancy in mice by oral administration of agroclavine and sclerotia of Claviceps fusiformis (Loveless). J. Reprod. Fertil. 18: 81-88.

Markstein R (1981) Neurochemical effects of some ergot derivatives: a basis for their antiparkinsonian actions. J. Neurol. Transm. 51: 39-59.

Papavasiliou PS, Cotzias GC, Rosal VLP, Miller ST (1978) Treatment of parkinsonism with n-propyl norapomorphine and levodopa (with or without carbidopa). Arch. Neurol. (Chicago), 35: 787-794.

Parkinson J (1817) Essay on the shaking palsy. Willingham and Rowland, London.

Pasteels JL (1973) Introduction. In: Human Prolactin, Pasteels JL and Robyn C (Eds.) Excerpta Medica. Amsterdam pp. xi-xiii.

Rascol A, Montastruc JL, Guiraud-Chaumeil B, Clanet M (1982) La bromocriptine comme premier traitement de la maladie de Parkinson - Résultats à long terme. Rev. Neurol. (Paris) 138: 367-385.

Ringwald E, Hirt D, Markstein R, Vigouret JM (1982) DopaminrezeptorenStimulatoren in der Behandlung der Parkinson-krankheit. Nervenarzt 53: $67-71$.

Rinne UK (1983) Dopamine agonists in the treatment of Parkinson's disease In: Advances in Neurology. Vol. 37. Experimental Therapeutics of Movement disorders. Fahn S et al., (Eds.) Raven Press, New-York pp. 141-150.

Schneider HR, Stadler PA, Stutz P, Troxler F (1977) Synthese und Eigenschaften vor Bromocriptin. Experientia. 33: 1412-1413.

Scholtysik G, Muller-Schweinitzer (1980) Evidence of presynaptic dopamine receptors in sympathetic heart nerves of cats. In: Modulation of Neurochemical Transmission Vizi ES (Ed.), London, Pergamon Press, Budapest, Akadémiai Kiado, p. 189.

Schwab RS (1951) Apomorphine in Parkinson's disease. Trans. Am. Neurol. Assoc. 76: 251-253.

Shelesnyak (1954) Ergotoxine inhibition of deciduoma formation and its reversal by progesterone. Am. J. Physiol. 179: 301-304.

Shelesnyak MC (1958) Maintenance of gestation in ergotoxine-treated pregnant rats by exogenous prolactin. Acta Endocr. (Copenh) 27: 99-109.

Shone DK, Philip JR, Christie GJ (1959) Agalactia of sows caused by feeding the ergot of the bulrush millet Pennisetum typhoides. Vet. Rec. 71: 129-132.

Thorner MO, Flueckiger E, Calne DB (1980) Bromocriptine. A Clinical and Pharmacological Review. Raven Press, New-York.

Tran MA, Montastruc JL, Montastruc P (1983) Bases pharmacologiques de l'utilisation thérapeutique des alcaloides de l'ergot de Seigle. Presse Med. 12: 517-520.

Turkington RW (1971) Measurements of prolactin activity in human serum by induction of specific milk proteins in mammary gland in vitro. J. Clin. Endocrinol. 33: 210-216.

Ungerstedt U (1971) Postsynaptic supersensitivity after 6-hydroxydopamine induced degeneration of the nigra-striatal dopamine system. Acta Physiol. Scand. 367: 69-93.

Vigouret JM, Burki HR, Jaton AL, Zuger PE, Loew DM (1978) Neurochemical and neuropharmacological investigations with four ergot derivatives. Pharmacology 16, Suppl. 1: 156-173.

Vigouret JM, Jaton AL, Enz A (1983) Chronic application of bromocriptine at low doses induces behavioural and biochemical hypersensitivity. In: First Symposium on Restorative Neurology, Venice p. 34 (abstr.).

Wong DT, Bymaster FP (1978) Interaction of ergot alkaloids with dopamine receptors in vitro. Am. Chem. Soc. Cent. Great Lakes Reg. Meet. 25, 11 (abstr.).

Wong DT, Bymaster FP, Lane PT, Kau D, Kornfeld EC (1979) $\left({ }^{3} \mathrm{H}\right)$-Pergolide binds to dopamine receptors in mammalian brain. NeuroSci. Abstr. (Soc. Neurosci.) 5: 577.

Zeilmaker GH, Carlsen RA (1962) Experimental studies on the effect of ergocornine methanesulfonate on the luteotrophic function of the rat pituitary gland. Acta Endocrinol. (Copenh.) 41: 321-330. 